\title{
Optimization Analysis Of Regional Resources Potential In Kphl Ternate-Tidore North Maluku
}

\author{
Andy Kurniawan ${ }^{1}$ Soemarno $^{2}$, Cahyo Prayogo ${ }^{2}$, Sujarwo ${ }^{2}$ \\ ${ }^{1}$ Department of Forestry, Faculty of Agriculture, Khairun University, Ternate, Indonesia \\ ${ }^{2}$ Department of Agriculture, Faculty of Agriculture, Universitas Brawijaya, Malang, Indonesia \\ *Correspondent author : staff_gambesi2@yahoo.com
}

\begin{abstract}
KPHL must have managerial capabilities, to make optimal use of the assets owned in their area, KPHL in carrying out management activities to generate income must be as an independent unit (self-financing management unit), so that the legality of ensuring investment activities and income management can be done independently. The potential of the Ternate-Tidore KPHL area is very large with a land cover dominated by forest, very diverse non-timber forest products, high potential for environmental services and natural tourism. This study aims to analyze the optimization of the natural resource potential of the Ternate-Tidore KPHL area. The research was conducted by processing map image data for land cover and field surveys using tracking lines to determine locations that have potential for environmental services and nature tourism as well as direct measurement observations in the field for potential timber and non-timber products,then processed the data and performed a SWOT analysis. Based on the results of the analysis, it was found that the potential of NTFPs with a volume of 410,253.22 Ha, the diverse potential of NTFPs was dominated by bamboo with production $(5,500 \mathrm{stems} /$ year $)$ with a total distribution area in the forest class of 3,723.63 Ha, and the mixed garden class of 4,273.43 $\mathrm{Ha}$. The results of the SWOT analysis resulted in an optimization strategy, namely (1). Institutional and human resource development strategy, (2). Strategy of cooperation with relevant stakeholders in the processing of potential resources and (3). Marketing strategy of the results of potential resources with innovative technology creatively.
\end{abstract}

Keywords: Area, Resources, Management, Forest

\section{Introduction}

Good forest management must be able to provide optimal benefits for the community, forest managers and stakeholders as well as the surrounding environment. Good forest management must also pay attention to aspects of forest sustainability, such as: ecological aspects, production, as well as socio-economic and cultural communities around the forest [1]. Forest Management Unit (KPH) is the smallest forest management unit according to its main function that can be managed efficiently and sustainably. Good forest management does not only pay attention to technical aspects of forest management, but also must pay attention to social aspects [2]. The background of the development of KPHL as a National Priority is in the context of preparing (Integrated Forest Base Clustering Industry) which is expected to be able to better distribute forestry businesses. KPHL is a forest management area according to its main function and designation and operationally must ful fill 3 activity components, namely: (1). Establishment of KPH area units in all forest areas so that there is certainty of management areas. (2). Establishment of a management institution in each KPHL unit, so that there is certainty of the person in charge of implementing management functions at the site level. (3). Preparation of forest management plans at the KPH level as an operational elaboration of achieving the targets of the district/city, provincial and national forestry plans. [3] concerning Forestry states that 
there are 3 forms of KPH, namely: (1). Conservation Forest Management Unit (KPHK) $\mathrm{KPH}$ in conservation forest. (2). Protection Forest Management Unit (KPHL)-KPH in protected forest and Production Forest Management Unit (KPHP)-KPH in production forest. The Ministry of Environment and Forestry's strategic plan has targeted $600 \mathrm{KPHs}$ to be formed, consisting of 530 KPHPs and KPHLs and 70 conservation forest management units (KPHK).

The process of developing KPHL in Maluku Province is based on the Decree of the Minister of Forestry number: SK.73/menhut-II/2010 concerning the determination of the areas for Protected Forest Management Units (KPHL) and Production Forest Management Units (KPHP) in North Maluku Province as many as 16 units. The determination of the Ternate-Tidore KPHL area based on the decision is $\pm 9,705$ Ha. On May 1, 2013, based on the Decree of the Minister of Forestry of the Republic of Indonesia Number: SK.302/MenhutII/2013, the government determined forest areas and certain areas designated as forest areas in the North Maluku Province based on the decree covering an area of $\pm 2,515,220$ (two million rupiah). five hundred fifteen thousand two hundred twenty) $\mathrm{Ha}$, including forest area in the Ternate-Tidore KPH area. The Ternate-Tidore $\mathrm{KPH}$ area which is located in Ternate City and part of Tidore Islands City is set at 8,499.61 Ha. Based on the Decree of the Minister of Forestry of the Republic of Indonesia Number: SK.302/Menhut-II/2013 concerning amendments to the decision of the minister of forestry and plantations number: 415/Kpts-II/1999, certain forests and areas designated as forest areas in the North Maluku Province are covering an area of \pm 2,515,220 (two million five hundred fifteen thousand two hundred and twenty) Ha. Until 2018, the function and area of the forest area as referred to in the Decree of the Minister of Forestry Number: SK.302/Menhut-II/2013 is included in the area manage the Ternate-Tidore KPH which is located on 9 (nine) islands, namely Mayau Island, Gurida Island, Tifure Island, Hiri Island, Ternate Island, Tidore Island, Maitara Island, Mare Island and Moti Island.

KPHL Ternate-Tidore is an UPTD of the Forestry Service of North Maluku Province, as explained in the Regulation of the Governor of North Maluku Number 69 of 2016 dated December 27, 2016 which has been revised by Regulation of the Governor of North Maluku Number: 44 of 2017 concerning the Establishment of a Regional Technical Implementation Unit for Forest Management Units at the North Maluku Provincial Forestry Service under the name KPH Ternate-Tidore. The Ternate-Tidore KPH area is an archipelago, consisting of 14 (fourteen) large and small groups of islands spread from the north, namely Mayau Island to the south, namely Moti Island, the total land area in this region is $\pm 29,004.86 \mathrm{Ha}$. This unique island region is a distinctive character ofKPHL Ternate-Tidore, each island has the potential of forests and interesting nature.

KPH activities refer to Government Regulation (PP) No. 6 of 2007 in conjunction with PP. No. 3 of 2008, concerning Forest Management and Preparation of Forest Management Plans and Forest Utilization.FMUs to be able to generate income to carry out their forest management activities in an independent unit (self-financing management unit), although it does not deny public investment into it because as a government entity, KPH must also carry out public functions such as job creation, growth business opportunities and environmental protection. Forest management and development involving the community is a new hope to be able to solve problems that occur in forestry development. KPH must have managerial capabilities, to make optimal use of assets owned in their area, and have the ability to market them to achieve independence, by determining the goals and objectives of the KPH, Designing a Business Plan, and implementing them, through the 6 M Principles (Money, Manpower, Materials, Methods, Machinery and Marketing). The realization of a business in the forestry sector with a core business through collaboration with the concept of collaboration between relevant stakeholders in forest utilization and 
management through 7 forest utilization activities, namely: utilization of environmental services, collection of timber and non-timber forest products, and nature tourism.

\section{Research methods}

\subsection{Research Time and Location}

Administratively, the management areas of the Ternate-Tidore KPHL which were used as research locations were Ternate Island, Tidore Island, Maitara Island and Hiri Island. The study location is in the utilization block, the total utilization zone is $5,059.73$ $\mathrm{Ha}$, while those managed through the partnership program are $302.65 \mathrm{Ha}$. The following is presented in Figure 1. Map of the Ternate-Tidore KPHL Forest Management Plan Location of the study plan related to the data and data sources as well as the analysis used. The activity was carried out July-November 2019.

Figure 1. Map of Ternate-Tidore KPHL Forest Management

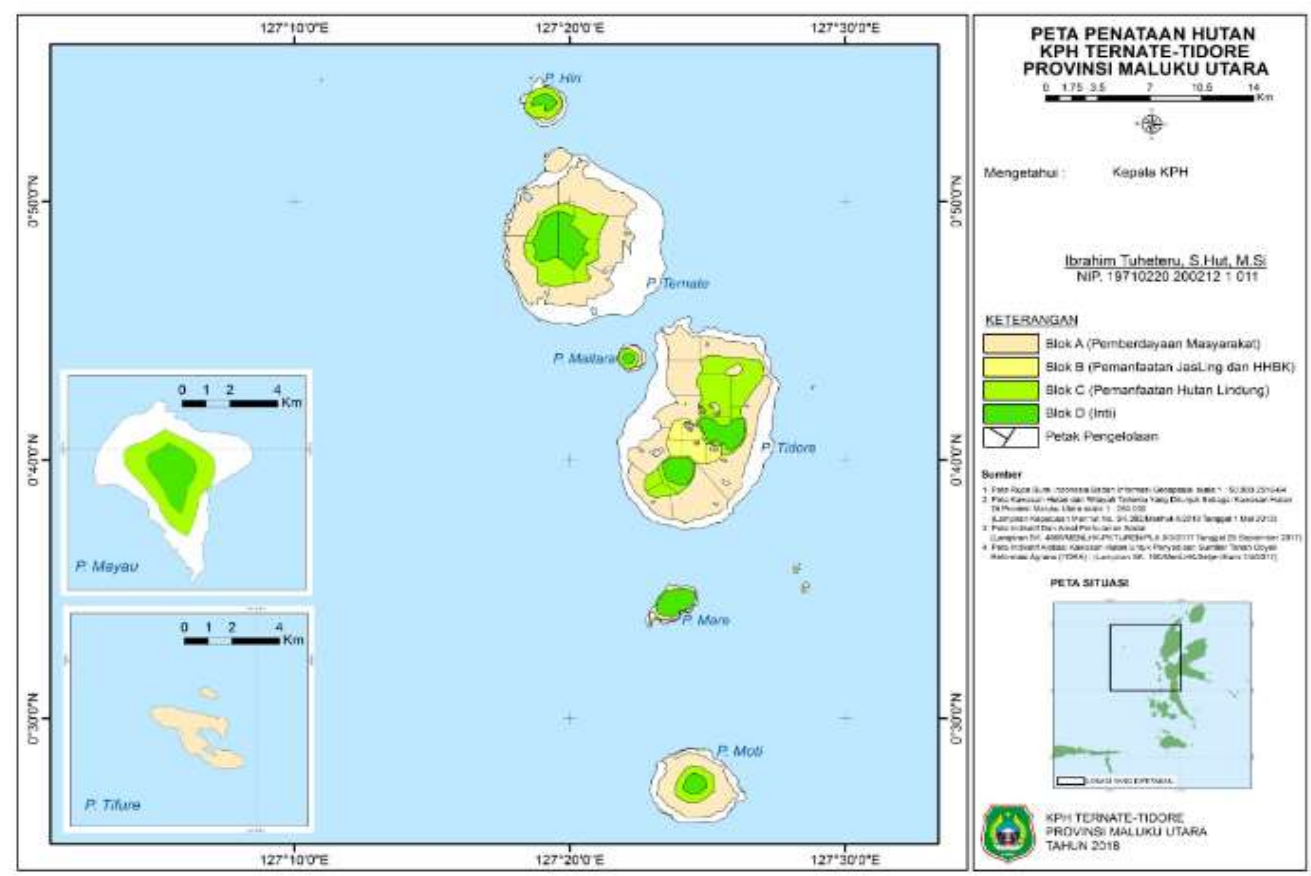

Source: RPHJP KPHL Area Map 2019-2028

\subsection{Data Retrieval Method}

The method used is descriptive qualitative and quantitative with field survey techniques. This study uses primary and secondary data. Field data collection is done by direct observation in the field/observation. The tools used to analyze the potential for environmental services and nature tourism are the Global Positioning System (GPS) as a recorder of coordinate points and tracking paths, ArcGIS 10.4 software which is used to process mapping data, stationery and digital cameras as documentation tools. The research was conducted by processing map image data for land cover and field surveys using tracking lines to determine locations that have potential for environmental services and nature tourism as well as direct field observations for potential timber and non-timber products, data collection techniques related to potential timber and NTFPs, conducted by purposive sampling where the sample is considered to have the information needed for this research. The placement of measuring plots (PU) is done intentionally with a combination 
method of path methods with plotted lines, the error allowed in data collection or plots of measuring plots is $15 \%$ with an accuracy level of $95 \%$ with IS 0.1 . The data analysis carried out in this study is a qualitative descriptive analysis to describe a SWOT analysis to formulate a strategy for optimizing timber and non-timber forest products and the use of environmental services and nature tourism. According to Wibawa (2013), the SWOT strategic planning process goes through three stages, namely: (a) Data collection stage, the model used in this stage consists of an external strategic factor matrix (EFAS) and an internal strategy factor matrix (IFAS). (b) The SWOT analysis stage, namely the preparation of a SWOT matrix that can produce four sets of possible strategic alternatives as shown in Table 3.1. and (c) Decision Making Stages SWOT analysis is also used to design strategic steps and assessments of strengths, weaknesses, opportunities, and threats, resulting in a strategy for developing area management for the sake of FMU independence. SWOT analysis method for formulating the concept of optimizing the potential of regional resources. The SWOT matrix analysis aims to identify strategic alternatives that are intuitively felt to be feasible and suitable to be implemented. SWOT Analysis Method.

Table 3.1. SWOT Analysis Method

STRENGTH

\section{ST}

Harnessing Potential To Face

Threats
WEAKNES

WT

Minimizing Weaknesses to Face Threats
SO

WO

OPPORTUNITIES Leveraging Potential to Seize

Opportunities
Overcoming Weaknesses to Seize Opportunities

\section{Results and Discussion}

\subsection{Ternate-Tidore KPHL Area Land Cover}

Based on the results of land cover mapping, the area dominated by plantation areas is 4,273.44 ha, which is an open monoculture garden planted with coconut, nutmeg and clove plantations. The location of the plantation is in a forest area that functions as a protected forest (HL), production forest (HP) and limited production forest (HPT) in the TernateTidore KPH area. The forest area in the KPH area consists of dry land forest and jungle forest covering an area of 3,723.63 Ha, which functions as a protected forest area. The land cover class in the form of forest is dry land forest and jungle forest which is dominated by Sengon, Nyatoh, Gosale and Gufasa tree species. The forest area includes dry land plantations mixed with shrubs, namely land planted with nutmeg, cloves, cinnamon, coconut, Cocoa and Fruiting Plants such as Mango, Durian, Langsat. The land cover in the form of gardens is dominated by Nutmeg and Clove plants while the fields are planted with several local agricultural commodities such as Cassava, Corn, Chili, Tomatoes and several types of vegetables. Fields, open agriculture, shrubs and grasslands covering an area of 396.89 hectares, which are dominated by people of productive age. [4] suggests that the productive age for work in developing countries is generally 15-55 years. The mangrove area in the Ternate-Tidore KPH area consists of primary mangrove forest and secondary 
mangrove forest. Mangrove areas are located on Tifure Island, Gurida Island, Moti Island and Mare Island. Mangrove forest is an important area in the preservation of terrestrial biodiversity such as reptiles and birds as well as a breeding area for several types of fish. In this area there are also vegetation types such as Avicenia sp., Rhizophora sp., Sonneratia sp., Calophyllum Inophyllum and Bruguiera sp. The area of mangrove forest in the Ternate-Tidore KPH area is 105.64 hectares. At the peak of Mt. Gamalama has an active volcanic crater area in the form of a stretch of sand, rocks and volcanic ash covering an area of 139.24 hectares. The following is presented in Table 3.1. The land cover area of the Ternate-Tidore KPHL area. At the peak of Mt. Gamalama has an active volcanic crater area in the form of a stretch of sand, rocks and volcanic ash covering an area of 139.24 hectares. The following is presented in Table 3.1. The area of land cover for the TernateTidore KPHL area. At the peak of Mt. Gamalama has an active volcanic crater area in the form of a stretch of sand, rocks and volcanic ash covering an area of 139.24 hectares. The following is presented in Table 3.1. The area of land cover for the Ternate-Tidore KPHL area.

Table 3.1. : Land Cover Area in Ternate-Tidore KPHL Area

\begin{tabular}{llr}
\hline No & \multicolumn{1}{c}{ Land Cover Class } & Area (Ha) \\
\hline 1. & Settlement & 11.9 \\
2. & Forest & $3,723.63$ \\
3. & Mangrove forest & 105.64 \\
4. & Logged Forest & 104.41 \\
5. & Grassland & 72.39 \\
6. & Shrubs & 68.22 \\
7. & Garden & $4,273.43$ \\
8. & Field & 0.83 \\
9. & Active Volcano Crater & 139.23 \\
TOTAL & $8,499.61$ \\
\hline
\end{tabular}

Source: Primary Data Processing

\subsection{Timber Product Potential (HHK)}

Based on the survey results and field sampling, the potential timber forest products commonly found in the Ternate-Tidore KPH management area are derived from Sengon, Nyatoh, Gosale, Gufasa, Samama and Jati plants in dryland forest. Other woody plants are species (Avicenia sp., Rhizophora sp., Sonneratia sp., Calophyllum inophyllum and Bruguiera sp), which grow in mangrove forests. The following is presented in Table 3.2.Timber Potential Estimation in Dry Land Forest in Ternate and Tidore.

Table 3.2. Estimation of Timber Product Potential in the Ternate-Tidore KPHL Area

\begin{tabular}{|c|c|c|c|c|}
\hline No & \multicolumn{3}{|c|}{ POTENTIAL OF TIMBER IN DRY LAND FOREST } & \multirow{2}{*}{$\begin{array}{l}\text { VOLUME } \\
\text { (M³/Year) }\end{array}$} \\
\hline & $\begin{array}{c}\text { LOCAL } \\
\text { NAME }\end{array}$ & LATIN NAME & $\begin{array}{c}\text { DISTRIBUTION } \\
\text { LEVEL }\end{array}$ & \\
\hline 1. & Sengon & Albizia chinensis & medium - high & 182.444 .40 \\
\hline 2. & Nyatoh & Sapotaceae spp & currently & $100,023,40$ \\
\hline 3. & Gosaleh & Eucalyptus spp & currently & $60,018.78$ \\
\hline 4. & Gufasa & Vitex Cofassus & low - medium & $40,012.54$ \\
\hline 5. & Samama & Same with cadamba & low & $17,585.61$ \\
\hline
\end{tabular}




\begin{tabular}{lrrr}
\hline 6. Teak & Tectona Grandis & low & \\
& & Amount : & 410,253.22 \\
\hline
\end{tabular}

Source: Primary Data Processing 2020

Estimated wood potential in the forest in the Ternate-Tidore KPHL with a total volume: 410,253.22 (M3/Year). The potential for timber products in the Ternate-Tidore KPHL management area with dynamics of distribution level is in the medium to high category, if not managed properly everything will become a low distribution level, reducing the area of critical land covering an area of 12,841.20 Ha to 11,341.20 every year causing the distribution rate to decrease for the types of wood commodities. The criticality level of land in the Ternate-Tidore KPHL area which is the focus of attention in the protected forest area, namely: Tidore Island $954.74 \mathrm{Ha}$, Ternate Island 264.19 Ha, Hiri Island 359.09 Ha, and Maitara Island 104.19 Ha.

\subsection{Potential Non-Timber Forest Products (HBBK)}

NTFPs economically have high economic value and have the opportunity to increase people's income and welfare, but business development and utilization of NTFPs has not been carried out intensively [5]. The potential of non-timber forest product resources of the Ternate-Tidore KPHL utilization level is from low to high category. NTFPs which have the potential to become superior commodities in improving the welfare of local communities and contributing to the region, will be able to develop a development strategy in accordance with the biophysical, social, economic and cultural conditions of the area and furthermore, cultivation and utilization efforts can be carried out in a more planned, focused and effective manner. The leading or popular NTFP commodity is bamboo which is used on a household scale for raw materials for hats (Tolu), pikul baskets (saloi) while on a large scale industrial scale is furniture such as tables, cabinets, booths, figures, souvenirs and souvenirs. Most NTFPs are traded on a small scale, local in nature, and even bartering in certain areas and conditions, so there must be a good marketing alternative, [6]. The following is presented in Table 3.3. NTFP potential in utilization level.

Table 3.3. NTFP Potential Yield by utilization rate

\begin{tabular}{clll}
\hline No & \multicolumn{1}{c}{ Type } & \multicolumn{1}{c}{ Utilization Rate } & \multicolumn{1}{c}{ Deployment Location } \\
\hline 1 & Bamboo Petung & Tall & P. Ternate, P. Tidore \\
2 & Spotted Bamboo & Tall & P. Ternate, P. Tidore \\
3 & Apus Bamboo & Tall & P. Ternate, P. Tidore \\
4 & Curry Bamboo & Tall & P. Ternate, P. Tidore \\
5 & Ultimate Bamboo & Tall & P. Ternate, P. Tidore \\
6 & Charcoal & Tall & P. Ternate, P. Tidore \\
7 & betel nut & Tall & P. Ternate, P. Tidore \\
8 & Sago & Tall & P. Tidore \\
9 & Nutmeg & Tall & P. Ternate, P. Tidore \\
10 & Clove & Tall & P. Ternate, P. Tidore \\
11 & Rattan & Low & P. Ternate, P. Tidore \\
12 & Aren & Low & P. Ternate, P. Tidore \\
13 & Essential oil & Currently & P. Ternate, P. Tidore \\
14 & Honey & Currently & P.Ternate \\
15 & Decorative plants & Currently & P. Ternate, P. Tidore \\
16 & Medicinal plants & Currently & P. Ternate, P. Tidore \\
\hline Sour
\end{tabular}

Source: Primary Data Processing 2020

The lack of data on the value of NTFPs is in accordance with what was stated by Wiratno (2014), that the problems faced in the utilization of NTFPs include the policy of 
developing NTFPs that is not carried out in an integrated manner and tends to be partial and NTFP production data is not yet available validly and adequately. The potential for NTFPs in the highest utilization is bamboo with a production $(5,500 \mathrm{stems} / \mathrm{year})$ which is the type used to withstand erosion and landslides, so it needs to be managed properly due to the increasing number of uses with a range of 1200 stems per ha. The land cover class area covered with bamboo in the Ternate-Tidore KPHL area for forest class is 3,723.63 Ha and mixed garden class is 4,273.43 Ha. So if the utilization is not balanced it will affect the rate of erosion and landslides even though from an economic point of view it is very profitable. Synergy between multi-stakeholders as well as good handling and management of resources are needed for the sustainable and sustainable development of superior NTFPs [7]. Participation from all parties in the management of NTFPs is highly expected, but it does not involve all stakeholders, because each stakeholder has their own main duties and functions [8]. Results of Potential Production of NTFPs in the Ternate-Tidore KPHL Area. Synergy between multi-stakeholders as well as good handling and management of resources are needed for the sustainable and sustainable development of superior NTFPs Table 3.4 is presented below.

Table.3.4. Results of Potential Production of NTFPs in the Ternate-Tidore KPHL Area

\begin{tabular}{clcc}
\hline No & \multicolumn{1}{c}{ Type } & \multicolumn{2}{c}{ Production (Kg/Ton/Liter/Type/Stem)/Year } \\
\cline { 3 - 4 } & & Ternate City & Tidore Island City \\
1 & Rattan & 2,500 sticks & 3,000 sticks \\
2 & Bamboo & 14,400 sticks & 19,200 sticks \\
3 & Sago & 134 tons & 167 tons \\
4 & Cinnamon & 8 tons & 10 tons \\
5 & Nutmeg & 1,032 tons & 177 tons \\
6 & Clove & 330 tons & 267 tons \\
7 & Palm sugar & 3 tons & 6 tons \\
8 & Clove Oil (essential) & 9,428 liters & 7,628 liters \\
9 & Honey bee & 60 liters & 84 liters \\
10 & Mold & $500 \mathrm{Kg}$ & $500 \mathrm{Kg}$ \\
11 & Ornamental Plants & $100 \mathrm{kinds}$ & $100 \mathrm{kinds}$ \\
12 & Cashew & 2 tons & 1 ton \\
\hline
\end{tabular}

Source: Primary Data Processing 2020

\subsection{Potential for Environmental Services and Nature Tourism}

Potential environmental services that can be developed are mangrove areas on the island, mountainous natural tourism, and waterfalls in the Ternate-Tidore KPHL management area among the natural tourist attractions (OTDW) as many as 4 (four) locations spread out. The following is presented in Table 3.5. Potential for environmental services and nature tourism.

Table 3.5. Potential for Environmental Services and Nature Tourism in the Ternate-Tidore KPHL Area

\begin{tabular}{clll}
\hline No & \multicolumn{1}{c}{ Potency } & Visitor Activities & \multicolumn{1}{c}{ Location } \\
\hline 1 & Mount Gamalama & Tall & P. Ternate \\
2 & Mount Kie Matubu & Tall & P. Tidore \\
3 & Luku Boar Waterfall & Low & P. Tidore \\
4 & Mangrove forest & Low & P. Maitara \\
5 & Tolire Lake Tour & Tall & P. Ternate \\
6 & KTh . Forest Tour & Tall & P.Ternate \\
\hline
\end{tabular}

Source: Primary Data Processing 2020 
The potential for environmental services and natural tourism that is the focus is Lake Tolire tourism which is a tourist area that is close to location access with an average daily visitor of about 346 visitors so that in a month around 10,380 people and during the year it can reach 124,856 visitors. Communities around the Lake Tolire area are greatly helped from an economic point of view because of their food trading activities, with a total of 64 people involved in tourism activities in this area, with 52 traders and 12 ticket keepers divided. The average trader's income per day is around 198,000 thousand with capital expenditure of 87,000 / day so that the net income is 111,000 thousand / day, so that in a month 3,300,000 and income of 40,950,000 / year. So that tourism activities have great opportunities if they are managed better.

\subsection{SWOT Analysis (Strengths-Weaknesses-Opportunities-Threats)}

\section{INTERNAL FACTORS}

\begin{tabular}{|c|c|}
\hline Strength (S) & Weakness (W) \\
\hline $\begin{array}{l}\text { 1. The potential area is } \\
8,499.61 \text { Ha which } \\
\text { consists of core } \\
\text { blocks, utilization } \\
\text { blocks and special } \\
\text { blocks. } \\
\text { 2. High and diverse } \\
\text { NTFP potential } \\
\text { 3. Jasling potential and } \\
\text { natural tourism } \\
\text { prospects. High local government } \\
\text { 4. } \\
\text { demmitment in } \\
\text { the regions. }\end{array}$ & $\begin{array}{l}\text { 1. Lack of data and } \\
\text { information on regional } \\
\text { potential } \\
\text { 2. Limited budgeting for } \\
\text { FMUs. } \\
\text { 3. The SARPRAS for } \\
\text { Forest Security and } \\
\text { Protection is not yet } \\
\text { complete. } \\
\text { 4. Not enough police } \\
\text { personnel. } \\
\text { 5. There are no block and } \\
\text { plot boundaries. } \\
\text { 6. The Ternate-Tidore KPH } \\
\text { has not yet implemented } \\
\text { PPK BLUD. } \\
\text { 7. Community institutions } \\
\text { are not yet optimal. } \\
\text { 8. Lack of development } \\
\text { synergy between } \\
\text { stakeholders. }\end{array}$ \\
\hline $\begin{array}{l}\text { Strategy } \\
\text { Alternative I }\end{array}$ & $\begin{array}{l}\text { Alternative (WO) Strategy } \\
\text { II }\end{array}$ \\
\hline $\begin{array}{l}\text { 1. The government's } \\
\text { commitment can } \\
\text { encourage the use of } \\
\text { all forest resources in a } \\
\text { sustainable and fair } \\
\text { manner for the } \\
\text { community. } \\
\text { 2. The government can } \\
\text { issue regulations on } \\
\text { the use of NTFPs } \\
\text { 3. The government can } \\
\text { issue regulations on } \\
\text { the use of } \\
\text { environmental services }\end{array}$ & $\begin{array}{l}\text { 1. KPHL must carry out an } \\
\text { inventory of potential } \\
\text { periodically for optimal } \\
\text { management } \\
\text { 2. Accelerate the } \\
\text { structuring of BLUD } \\
\text { KDP plans for } \\
\text { independent } \\
\text { management } \\
\text { 3. Increased budget for } \\
\text { sapras and forest security } \\
\text { protection } \\
\text { 4. Accelerating the } \\
\text { independence of KPHL }\end{array}$ \\
\hline
\end{tabular}


services

4. There are many kinds of investment in goods and services from the TernateTidore KPH, including NTFPs, JASLING, and others.

5. High community participation/potential for community empowerment in developing forests and forestry through HKm and HD.

6. The issue of global warming.
4. Local government commitments can help accelerate the implementation of forest use

5. Community participation can be used as collaborative capital in area management

6. Manager carbon mechanism in managing potential resources by improving the quality of human resources

5. Strengthening KPHL collaboration with communities in utilization blocks

6. The large potential of the region can open up opportunities for collaboration with various stakeholders in the utilization of resource results.

\begin{tabular}{|c|c|c|}
\hline Challenge (T) & $\begin{array}{l}\text { Strategy } \\
\text { Alternative III }\end{array}$ & $\begin{array}{l}\text { Strategy (WT) Alternative } \\
\text { IV }\end{array}$ \\
\hline $\begin{array}{l}\text { 1. The extent of the critical land } \\
\text { is } 12,841.20 \text { ha with a target } \\
\text { of } 1,500 \text { ha for } 10 \text { years in the } \\
\text { Ternate-Tidore KPH area. } \\
\text { 2. High rates of degradation and } \\
\text { deforestation. } \\
\text { 3. The rise of logging and illegal } \\
\text { logging activities. } \\
\text { 4. Lack of community } \\
\text { knowledge about the role and } \\
\text { function of forests for life. } \\
\text { 5. There is still an assumption } \\
\text { that the } \\
\text { existence/operationalization of } \\
\text { FMUs will burden the APBD. }\end{array}$ & 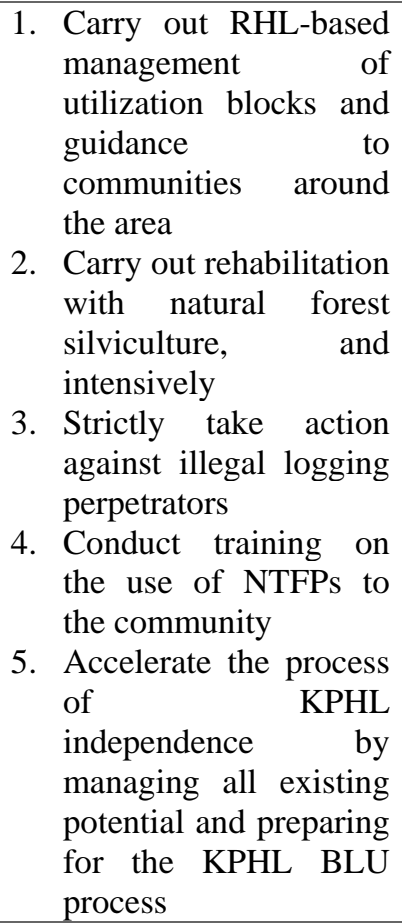 & $\begin{array}{l}\text { 1. Carry out regular } \\
\text { boundary and RHL } \\
\text { arrangements } \\
\text { 2. Strengthening KPHL } \\
\text { area management } \\
\text { institutions } \\
\text { 3. Opening opportunities } \\
\text { for collaboration or } \\
\text { collaboration with } \\
\text { various parties related to } \\
\text { RHL } \\
\text { 4. Speed up the BLUD } \\
\text { PPK process so that the } \\
\text { potential utilization of } \\
\text { the Jasling NTFP area } \\
\text { can be optimally } \\
\text { 5. Increase synergy to } \\
\text { increase community } \\
\text { capacity }\end{array}$ \\
\hline
\end{tabular}

\section{Source: Primary Data Processing 2020}

In detail, the general description of all development strategies for optimizing resource potential in the Ternate-Tidore KPHL area can be described as follows:

\section{(1). Strategy for optimizing resource potential in the Ternate-Tidore KPHL area. Alternative I}

SO Strategy : namely increasing the potential and strength to take advantage of existing opportunities, in this scenario a development strategy is carried out with alternatives:

1. The government's commitment can encourage the use of all forest resources in a sustainable and fair manner for the community.

2. The government can issue regulations on the use of NTFPs 
3. The government can issue regulations on the use of environmental services

4. Local government commitments can help accelerate the implementation of forest use

5. Community participation can be used as collaborative capital in area management

6. Manager prepares carbon trading mechanism

(2). Strategy for optimizing resource potential in the Ternate-Tidore KPHL area. Alternative II

WO Strategy : This strategy carries out efforts to minimize weaknesses to be able to attract existing opportunities, in implementing alternative strategy II it seems that it lies in efforts to develop institutions and human resources. These institutions and resources are directed to be able to handle all aspects of developing opportunities for the use of regional resources, in this scenario a development strategy is implemented with the following alternatives:

1. KPHL must carry out an inventory of potential periodically for optimal management

2. Accelerate institutional arrangement and planning of BLUD KDP for independent management

3. Increased budget for sapras and forest security protection

4. Accelerating the independence of KPHL in managing potential resources by improving the quality of human resources

5. Strengthening KPHL collaboration with communities in utilization blocks

6. The large potential of the region can open up opportunities for collaboration with various stakeholders in the utilization of resource results.

(3). Strategy for optimizing resource potential in the Ternate-Tidore KPHL area. Alternative III

ST Strategy:This strategy is intended to develop strength to make it easier to solve problems and challenges. This third strategy is related to efforts to carry out cooperation with all stakeholders in terms of managing the potential resources of the Ternate-Tidore KPHL area for the welfare of the surrounding community and the public interest, as for several alternative strategies in development as follows:

1. Conducting RHL by involving all stakeholders based on the management of utilization blocks and fostering the community around the area

2. Carry out rehabilitation with all stakeholders in silvicultural natural forest, and intensively

3. Strictly take action against illegal logging perpetrators

4. Conduct training on the use of NTFPs to the community

5. Accelerate the process of KPHL independence by managing all existing potential and preparing for the KPHL BLU process

(3). Strategy for optimizing resource potential in the Ternate-Tidore KPHL area. Alternative IV

WT Strategy: This strategy seeks to address weaknesses and eliminate challenges, which are related to marketing strategies and create opportunities that can be developed by utilizing the potential of regional resources so that it is hoped that innovations and creations that have high creativity will produce works that are useful for the development of science and technology for the sake of improving welfare. communities around forest areas.

1. Strengthening cooperation in marketing products resulting from potential resources 
2. Strengthening institutions in collaborative technology-based KPHL area management

3. Opening opportunities for collaboration or collaboration with various parties in improving applied technology

4. Speed up the BLUD PPK process so that the potential utilization of the Jasling NTFP area can be optimally

5. Increase synergy to increase community capacity

\section{CONCLUSION}

1. Timber potential in the forest in the Ternate-Tidore KPHL with a total volume: 410,253.22 (M3/Year). The potential for timber yields in the Ternate-Tidore KPHL management area with a dynamic distribution level is in the medium to high category, if not managed properly it will all become a low distribution level.

2. The potential for NTFPs in the highest utilization is bamboo with a production (5,500 stems/year) which is the type used to withstand erosion and landslides, so it needs to be managed properly due to the increasing number of uses with a range of 1200 stems per ha. The land cover class area covered with bamboo in the TernateTidore KPHL area for forest class is $3,723.63 \mathrm{Ha}$ and mixed garden class is 4,273.43 Ha. So if the utilization is not balanced it will affect the rate of erosion and landslides even though from an economic point of view it is very profitable.

3. The potential for environmental services and natural tourism that is the focus is Lake Tolire tourism which is a tourist area that is close to location access with an average daily visitor of about 346 visitors so that in a month around 10,380 people and during the year it can reach 124,856 visitors.

4. SWOT analysis focuses on Optimization (1). Efforts to develop institutions and human resources. These institutions and resources are directed to be able to handle all aspects of developing opportunities for utilizing regional resources, (2). Efforts to carry out cooperation with all stakeholders in terms of managing the potential resources of the Ternate-Tidore KPHL area for the welfare of the surrounding community and the public interest, (3). Marketing strategy efforts and creating opportunities that can be developed by utilizing the potential of regional resources so that innovations and creations are expected to emerge that have high creativity and produce works that are useful for the development of science and technology to improve the welfare of communities around forest areas.

\section{BIBLIOGRAPHY}

[1] Prayoto, "Analysis of Forest and Land Fires in Riau Province Based on The Use of Land for Mitigation of Smoke Disaster Analysis of Forest and Land Fires in Riau Province Based on The Use of Land for Mitigation of Smoke Disaster," no. December, pp. 5-7, 2011.

[2] I. S. ASTUTI, "Impact of Land Use Land Cover Change on Streamflow of Punpun River," no. July, pp. 1-192, 2013.

[3] R. Indonesia, "Presiden republik indonesia," no. 1, 1999.

[4] D. V Johnson and S. Livelihoods, Sago Palm. .

[5] T. Hayes and L. Persha, "Forest Policy and Economics Nesting local forestry initiatives : Revisiting community forest management in a REDD + world," For. Policy Econ., vol. 12, no. 8, pp. 545-553, 2010, doi: 10.1016/j.forpol.2010.07.003.

[6] F. Irauschek et al., "Evaluating five forest models using multi-decadal inventory data from mountain forests," Ecol. Modell., vol. 445, no. July 2020, 2021, doi: 10.1016/j.ecolmodel.2021.109493.

[7] S. Pengembangan, P. Alam, and P. Oktadiyani, "TAMAN WISATA ALAM WERA 
ECOTOURISM DEVELOPMENT STRATEGY OF WERA NATURE RECREATION PARK ( NRP )," no. November 1980, pp. 9-20, 2015.

[8] I. C. Mandang, B. J. V Polii, H. Walangitan, D. Kelompok, T. Sinoran, and K. Pasan, "PENDAHULUAN Latar Belakang Hasil Hutan Bukan Kayu ( HHBK ) merupakan salah satu sumberdaya hutan yang memiliki keunggulan komparatif dan bersinggungan langsung dengan masyarakat sekitar hutan ( Departeman Kehutanan , 2010 ). HHBK secara ekonomis memiliki ," vol. 14, no. September, pp. 1-16, 2018.

[9] Rawung, J. B. M., Sahara, D., Indrasti, R., Fadwiwati, A. Y., \& Yapanto, L. M. (2021). INCREASING FRUIT YIELDS AND INCOME OF RED CHILI FARMING BY USING CHEMICAL AND BIOLOGICAL FERTILIZERS IN RAINFED RICE. 20(2), 1-10.

[17] Sahara, D., Hartoyo, B., Fadwiwati, A. Y., Yapanto, L. M., Science, M., \& Indrasti, R. (2021). THE IMPROVEMENT PRODUCTION AND EFFICIENCY OF UPLAND RICE IN BOYOLALI DISTRICT CENTRAL JAVA, INDONESIA. 20(2).

[18] Muhaimin, A. W., Toiba, H., Retnoningsih, D., \& Yapanto, L. M. (2020). The Impact of Technology Adoption on Income and Food Security Of Smallholder Cassava Farmers: Empirical Evidence From Indonesia. 29(9), 699-706. 